\title{
The Origin of Arabic Lexicography: Its Emergence and Evolution
}

Niken Nur Hanifah', Email: nikennhanifa89@gmail.com, UIN Syarif Hidayatullah Jakarta, Indonesia

\section{(ब) (1) ()}

This is an open-access article under the CC-BY-SA license

(C)2021 by the authors. Submitted for possible open access publication under the terms and conditions of the Creative Commons Attribution-ShareAlike 4.0 International License-(CC-BY-SA) (https://creativecommons.org/licenses/by-sa/4.0/)

di) DOI: http://dx. doi.ong/10.30983/buruf.v1i1.4932

\begin{abstract}
This study aims to identify and describe 1) the history of the emergence and evolution of Arabic lexicography, 2) the implications of Arabic lexicography for learning Arabic. This research is a historical study using a qualitative approach with library research methods and documentation techniques. The data analysis used in this research is descriptive qualitative analysis. The results of the analysis show that 1) the emergence of al fikr al mu'jamiy was based on the difficulty of Arabs in understanding the meanings contained in the Qur'an which was named as gha>ri>bu al Quran, during this evolution period of Arabic lexicography gave an impact against the emergence of variations of the Arabic lexicon and entry systems with its characteristics one each other. This variety is the pure thought and innovation by lexicologists at that time in order to find the most appropriate method and system to codify Arabic vocabulary to make the Arabic lexicon provide an umbrella that can protect the purity and sustainability of the Arabic language from the challenges, 2) Arabic lexicography has a big impact in learning Arabic in the fields of morphology, syntax, and semantics which are language subsystems.
\end{abstract}

Keywords: lexicography, lexicon, vocabulary

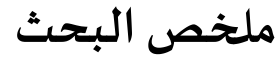

تهدف هذه الدراسـة إلى تحديد ووصف 1) تاريخ نشوء وتطور المعجم العربي ، 2) آثار المعجم العربي على تعلم اللغة العربية. هذا البحث دراسـة تاريخية باستخدام منهج نوعي مع أساليب البحث في المكتبات وتقنيات التوثيق. تحليل البيانات المستخدم في هذا البحث هو تحليل وصهي نوعي. وتبين نتائج التحليل أن 1) ظهور الفكر المعجهي كان قائماً على صعوبة فهم العرب لمعاني القرآن التي سميت يغريب القرآن خلال هذا التطور. أعطت فترة المعجم العربي تأثيرًا مرة أخرى على ظهور اختلافات في المعجم العربي وأنظمة الإدخال بخصيائصها بعضها البعض. هذا التنوع هو الفكر الخالص والابتكار من قبل علماء المعاجم في ذلك الوقت من أجل إيجاد الطريقة والأنظمة الأنسب لتدوين المفردات العربية لجعل المعجم العربي يوفر مظلة يمكن أن تحمي نقاء 


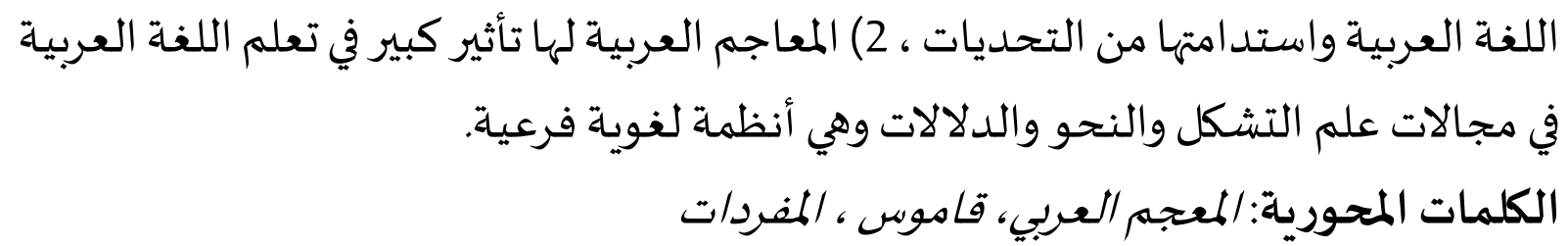

\section{INTRODUCTION}

Arabic experiencing rapid growth at the end of ignorance, these developments occurred in almost all lahjat used by several different tribes, which have an impact on the birth of literary language is taken from the overall different lahjats. In the end, the literary language was used in the form of speech, prose, poetry to maintain its purity and sustainability, at this time the term fushah language emerged. When the Arabs felt the beauty of their language, there were attempts to master it and various competitions around literature in the markets by the khutaba' and syuara' to show their abilities and skills. To maintain the preservation and purity of their language the Arabs also sent their children to live and direct contact with the khutaba' and syuara' so that they could learn and memorize the poems and follow in their footsteps in the future.

The development of language, which began with the spoken language phase before the written language phase, eventually led to the decline and even to the extinction of the language itself before the speakers started writing, as happened in the Samiyah, Akkaida, Assyuriah languages. Indeed, a person will find it difficult to memorize the entire vocabulary of a people's language even though he has the power to think and remember, in this case, the necessary for $m u^{\prime} j a m$ increasingly clear and real as an effort to maintain the purity and sustainability of a language in addition to other academic and scientific purposes.

The Arab population during the jahiliyah period was mostly illiterate which made the Arabs Lagging in terms of codifying their language compared to other nations such as India, China, and Greece. In addition, the fanaticism of spoken language for the sake of communication, poetry, makes the Arabs ignore the writing of words and their meanings. Before the arrival of the Abbasid era, Muslims were not fully aware of the necessity for a codification of the Arabic language. Until the 1st century hijriah or coinciding with the 7th century AD, enthusiasm for the study of the Qur'an was increasingly widespread, since then great attention to the vocabulary of the Qur'an began to grow which called by al gharib, so that they began to be preoccupied with $t a^{\prime}$ wil, analyzing and discussing the meaning of the language carefully. The widespread of Islam has also made non-Arabs flock to Islam, which makes the necessity for a systematic study of the Arabic language increasingly needed to guard against misreading and interpretation of the Qur'an and make it easier for non-Arabs to study Arabic in order to create unity of ummah. The assimilation of the purity of the language in the Qur'an with non-Arabic languages became the forerunner of the birth of two sciences, namely the science of Nahwu and the science of Arabic Lexicography. ${ }^{1}$

The attention and sympathy of the ulama for the need for this mu'jam was finally realized in the form of lexicographic activities which had gone through a long phase which in the end gave birth to various great works which became invaluable heritage and scientific treasure. It was recorded that from the second year of Hijriyah, the composition of mu'jam

\footnotetext{
${ }^{1}$ Mahdi Inaayaah Kareem al Uthbi \& Sundus Muhsin al Ubaidy, Approaches to Lexicography in English and Arabic, in LARQ Journal for Philosophy and Linguistic and Social Science [Online], Vol. 7, 2012, p. 13
} 
began to appear, beginning with Khalil ibn Ahmad's monumental work entitled by Kita>bu al 'Ayn which was then continued by his successor lexicologist, thus giving birth to various patterns and systems for the preparation of varied Arabic lexicon. ${ }^{2}$ Without the abundance of Arabic literature on Islam it would be difficult to understand even for Arabs, and the facts about Islam would be flawed and difficult to uncover.

Based on the background of though above, the research questions can be formulated as 1) How did the history of the emergence of Arabic lexicography?, 2) How did the evolution of Arabic lexicography evolve?, 3) What are the implications of Arabic lexicography for Arabic teaching and learning?. And the purpose of this research is 1) to know the chronology of the emergence of Arabic lexicography, 2) to know the evolutionary process of the development of Arabic lexicography, 3) to know the implications of Arabic lexicography on Arabic learning and teaching.

The existence of several studies around Arabic lexicography indicates that this research is not the only one, while among previous studies that have studied Arabic lexicography are the research by Alif Cahya Setiadi under the title Ta>ri>khu nasy'ati al Ma'a>jim al 'Arabiyyah', the research by Fitra Hayani under the title Leksikografi Arab (Sebuah Kajian Lingustik Terapan $)^{4}$, and the research by Mohammad Hassan Edrisi under the title a Study of Arabic lexicons their compilation methods and development. ${ }^{5}$

\section{RESEARCH METHODS}

This research is a historical study using a qualitative approach with library research methods and documentation techniques. The data analysis used in this research is descriptive qualitative analysis. This research is included in a historical study that seeks to reveal and describe past events surrounding the beginning and development of the codification of Arabic vocabulary so that it becomes a lexicon with a system and pattern of arrangement or special entries with different characteristics in each phase. In addition, this research is included in historical research that discusses the background of Arabic lexicography, its emergence, its evolution, and its implications on Arabic learning and teaching.

The researcher uses the method of documentation in the form of writing, pictures, works to collect data from non-human sources, namely documents related to the history of Arabic lexicography, profiles, and characteristics. To interpret the data obtained, the researcher uses the theory of the development of Arabic lexicography to describe the facts from the data that has been obtained. Furthermore, the description is in the form of a systematic history series by taking into account the chronological aspect.

\footnotetext{
${ }^{2}$ Muhammad Abu Al Farj, al Ma'a >jim al Lughawiyyah fi > Dhau'I Dira $>$ sa $>t$ 'Ilm al Lughah al Hadist, (Kairo: Da>r an Nahdhoh al 'Arabiyyah, 1966), p.29

${ }^{3}$ Alif Cahya Setiadi, Tarikhu Nasy'ati al Ma'ajim al 'Arabiyyah, in Journal Lisanu Dhad [Online], Vol. 02, No. 2, 2015

${ }^{4}$ Fitra Hayani, Leksikografi Arab (Sebuah Kajian Lingustik Terapan), in Journal Shaut al 'Arabiyyah [Online], Vol. 7, No.1, 2019

${ }_{5}$ Mohammad Hassan Edrisi and Gholamhossein Sharifi, A Study of Arabic Lexicon their Compilation Methods and development, in Journal of Novel Applied Sciences [Online], Vol. 04, No. 2, 2015
} 


\section{FINDINGS AND DISCUSSION}

\section{Definition of Al Mu'jam}

In language, mu'jam comes from the word أعجم which means أعجم الكلام the opposite to the word of أعرب. Mu'jam is also called القواميس or القاموس which comes from Fairuzabardy's naming of his work القاموس المحيط which means البحر المحيط or broad and complete. ${ }^{6}$ This Arabic word is derived from the Greek language "Okeanos", which means ocean as a form of knowledge container containing an infinite vocabulary breadth and depth. Umar Ahmad Mukhtar said that the Qur'an is an array of planning and writing of the vocabulary specific to the system and approach as المكانز or thesauruses, المسارس or glossaries, concordances the same function together to provide knowledge about the meaning of a vocabulary of a particular language. ${ }^{7}$

According to Abu Sikkin, mu'jam is a book that collects a large number of language vocabularies followed by explanations and interpretations of their meanings by classifying and

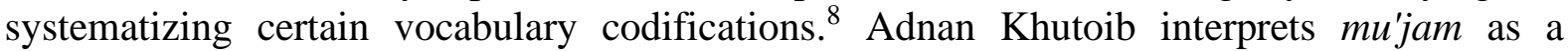
collection of linguistic vocabularies which are arranged based on hijaiyyah letters which is a great legacy left by scholars from time to time to maintain the purity of the Arabic language and the language of the Qur'an. ${ }^{9}$ The definition of al mu'jam or al qamus according to Eimil Yaqub is a book that collects a large number of language vocabularies accompanied by explanations, and interpretations of their meanings with a certain entry system, while al mu'jam al ka<mil is a book that collects language vocabulary that accompanied by an explanation of the meaning, an explanation of the derivation of the word, and how to pronounce it, as well as examples of the use and placement of the word in a sentence. ${ }^{10}$ While Hilmi Khalil distinguishes two general and specific definitions of mu'jam itself, in general mu'jam is a collection of lexical meanings from a language used by members of a particular language group to achieve its goals, while specifically mu'jam is a collection of vocabulary that is arranged into a special with a certain pattern and system of arrangement can be shaped as mu'jam which compiled by individuals such as Mu'jam Ibn Khaldun or it may be the comprehensive mu'jam such as kita>bu al 'Ayn works of Khalil. ${ }^{11}$

The term mu'jam was used by Imam Bukhari first to describe one of his books which were compiled based on the hijaiyyah letters. And some scholars who use the term $m u^{\prime} j a m$ to name their works include Abu al Qasim Abdullah ibn Muhammad in his work Mu'jam al H\}adi>ts and Mu'jam al S\}ah\}a>bah, Abu Bakr Muhammad ibn Hasan an Naqasy who compiled the Big Dictionary of the name of Qura' and summarized it in a small dictionary,

${ }^{6}$ Abdullah Muhammad An Nuqrath, al Sya >mil fi > al Lughah, (Libya: Da>r al Kutub al Wathaniyyah, 2003), p. 128

${ }^{7}$ Ahmad Mukhtar Umar, S\{ina > 'atu al Mu'jam al H\{adi>ts, (Kairo: ‘A>lamu al Kutub, 2009), p. 19-20

8 Abdul Majid Muhammad Abu Sikkin, al Ma'a>jim al 'Arabiyyah Mada>risuha> wa Mana>hijuha>, 2nd ed., (Kairo: 1981), hlm. 8

9 Adnan Quthaib, al Mu'jam al 'Arabiy baina al Madhy wa al Ha>dir, 2nd ed., (Libanon: Maktabah Lubnan li al Nasyirin, 1994), p. 36

${ }^{10}$ Eimil Ya'qub, Al Ma'a >jim al Lughowiyyah al 'Arabiyyah Bada > 'atuha> wa Tatawwuruha>, 1st ed., (Beirut: Dar al 'Ilm li Al Malayin, 1981), p. 9

${ }^{11}$ Hilmy Khalil, al Dira >sa>t fi > al Lughah wa al Mu'jam, 1st ed., (Beirut: Da>r al Nahdhoh, 1998),

p. 470 
Ibrahim ibn Ahmad al Balkhy who compiled Mu'jam li al Syuyu>kh, Abu Abdullah Muhammad ibn Imran Al Murzabaniy who compiled Mu'jam li al Syu'ara >'. From that moment on, every book that was compiled based on the hijaiyyah letters was named with mu'jam. Entering the fourth-century Hijriyah, the composition of mu'jam began to be influenced by scientific purposes, so that lexicologists at that time no longer used the naming of $m u^{\prime j} j \mathrm{~m}$ for their works, but they choose special names that characterize and highlight their work. Characteristics of these works as the work of Khalil ibn Ahmad al Farahidy named al 'Ayn. ${ }^{12}$

The variety of mu'jam 'arabiy that has been compiled by scholars since the second century Hijriyah can be categorized into two types, namely mu'jam ma'any or thematic lexicon and $m u^{\prime} j a m$ alfadz or literal lexicon. Thematic lexicon is a collection of vocabulary arranged according to a particular theme. The thematic lexicon is widely used in the field of translation, scientific research, syi'ir and khitabah, examination and testing of ancient Arabic texts and manuscripts, and laying out thematic vocabulary across disciplines. The literal lexicon is a collection of vocabulary that is arranged based on the lexeme of a word that contains an explanation of the meaning of the word, the model of its use in examples adapted from the words of the Arabs, the Qur'an, and Hadith. ${ }^{13}$ In the history of Arabic lexicography, Khalil ibn Ahmad al Farahidy had a major role in the compilation of the first Arabic lexicography using a phonetic system. Which is according to George Zaidan was the fruit of the influence of the Indian lexicologist who compiled the Sanskerta vocabulary starting with the halaq letters and ending with the syafawiy letters. ${ }^{14}$

The diversity of methods and systems of compiling mu'jam 'araby cannot be viewed as a matter of technicality and art alone. Mu'jam as a product of thought is an extension of the theories of thought and schools of thought at the time of its preparation which in the end has a lot of influence on the expansion of the application of its basics to the Arabic language, so that in the end, from the past until now the language can be maintained and glorified by this theories. ${ }^{15}$ There are two basic phases in the process of compiling mu'jam, namely al jam' $u$ and al wadh'u, first, is al jam'u related to the process of collecting material in the form of vocabulary and terms and classifying them based on lafadz, abniyyah, and the desired meaning, secondly is al wadh'u which is related to the process of compiling mu'jam material based on a certain approach and system. This process includes two things, namely $a l$ tarti $>b$ which in the history of Arabic lexicography has several madrasah or schools of arrangement or entries based on certain systems, patterns, and al ta'ri $>\mathrm{f}$ which is related to giving an explanation of the meaning of each vocabulary and terms. ${ }^{16}$ The synergy between these two fundamental processes that ultimately affect the quality of the Qur'an, because the al jam' $u$ good accompanied by ongoing al wadh'u bad or otherwise process al wadh'u qualified but begins with the quality of al jam'u will never be a combination and synergy that will give birth to a good and quality of $\mathrm{mu}^{\prime} \mathrm{jam} .{ }^{17}$

Abu Sikkin mentions that among the importance of mu'jam for language learners in the modern era is the mastery of Arabic vocabulary is limited to one's culture and level of productivity so that if the learner is faced with Arabic scripts that are contrary to his field, he will need mu'jam to can arrive at the understanding of the desired meaning, besides the need for $m u^{\prime} j a m$ has also existed for a long time, the ancient syi'ir tradition required everyone to

12 Adnan Quthaib, al Mu'jam al 'Arabiy baina al Madhy wa al Ha>dir...,p. 32-33

13 Abdullah Muhammad An Nuqrath, al Sya>mil fi> al Lughah..., p. 138-141

${ }^{14}$ George Zaidan, Tari >kh Adab al Lughah al 'Arabiyyah, 1st, (Beirut: Da>r al Fikr), p. 132

15 Muhammad Rasyad al Hamzawiy, Min Qadha>ya> al Mu'jam Qadi>man wa Hadi>tsan, 1st ed., (Tunisia: Dar Gharb al Islamiy, 1986), p. 52

${ }^{16}$ Ibrahim ibn Murad, Masa>il fi > al Mu'jam, 1st ed., (Beirut: Da>r al Gharby al Islamiy, 1997), p. 95

17 Muhammad Rasyad al Hamzawy, Min qadha>ya> al Mu'jam al' Araby Qadi>man wa Hadi>tsan, 1st ed., (Beirut: Da>r al Gharby al Islamiy, 1986), p. 149 
master the entire vocabulary of the existing language. The assumption that every Arab understands every sentence he hears is wrong, so someone with weakness and limited understanding will return to the use of mu'jam itself to find out every meaning of the sentence in question. ${ }^{18}$

\section{The Emergence of Arabic Lexicography}

During the period of ignorance, the Arabs did not realize the necessary of $m u^{\prime} j a m$ until the advent of Islam. Imeil Ya'qub mentions the reason behind this phenomenon is the bigotry of syi'ir, khitobah, and muhadatsah as the goal of using spoken language in the context of communicating with other people, the Arabs who are mostly illiterate, and the lack of someone who is able to read and write, and traditions of nodamism and war made the Arabs not pay attention to the importance of written language in the form of mu'jam. ${ }^{19}$ This factor causes the Arabs to lag behind other languages in codifying vocabularies, such as Chinese, Roman, and Greek.

But over time until the arrival of Islam in the Arabian Peninsula, attention to written language in addition to spoken language is no longer sidelined. Abu Sikkin mentions that Arabic lexicography began when the Arabs began to face difficulties in understanding the meanings contained in the Qur'an which named by gha>ri>bi al Quran, and they were looking for the meaning of the unknown words in the syi'ir as it has been narrated that Sa'id bin Jubair and Yusuf bin Mahran when they asked Ibn 'Abbas about gha>ri>bi al Quran, then Abdullah bin 'Abbas replied to look for it in Syi'ir Di>wa>ni al 'Arab. Abu Sikkin also mentioned that Ibn 'Abbas was approached by a man and asked him about the meaning and interpretation of the sentence in question نضججه وبلاغاء then Ibn Abbas answered إذا أثمر وينعاء and the sentence الدين والطريق مُ2. This conversation or in history is called $s u^{\prime} a>l a>t n a>f i$ 'ibn al-Azraq is a forerunner to the birth of the science of Tafsir and is much in use by qudama lexicologist as an indication of the birth of Arabic lexicography.

The Muslims in the era of the reign of the caliph Abu Bakr As Siddiq began to expand their territory towards Persia, and Persia could be opened by Muslims in the reign of the caliph Umar bin Khattab. At that time, non-Arabs flocked to Islam and began to learn Arabic as the language of the new religion. This triggers the spread of land that often occurs in the study of the holy book of the Qur'an including lahn makharij al hurf and lahn fi> nut \}qi al as \}wat and lahn fi>tarki>b al jumal and lahn fi> al i'rab. This land phenomenon was not limited to nonArabs but also happened to some Arabs at that time. In this case, it can be concluded that there is a close relationship between language studies and religious studies.

Abu Sikkin mentions that among the factors in the preparation of mu'jam is the need of the Arabs for the interpretation of the Qur'an and protection from errors in pronunciation and understanding. In addition, the emergence of works about gha>ri>bi al Quran pioneered by Ibn Abbas which is increasing day by day, followed by the emergence of syarh against

18 Abdul Majid Muhammad Abu Sikkin, al Ma'a>jim al 'Arabiyyah Mada>risuha> wa Mana> hijuha>..., p. 5

24

${ }^{19}$ Eimil Ya'qub, al Ma'a >jim al Lughowiyyah al 'Arabiyyah Bada> 'atuha> wa Tatawwuruha> ..., p.

${ }^{20}$ Abdul Majid Muhammad Abu Sikkin, al Ma'a >jim al 'Arabiyyah Mada >risuha> wa Mana>hijuha..., p. 16 
gha>ri>bi al hadith and continued with the emergence of syarh against at turats asy syi'riy. And the emergence of various scientific disciplines such as Fiqh, Balaghoh, Qiro'ah, and Nahwu whose main purpose is none other than memorizing and interpreting the Qur'an, as well as the fears of scholars about the loss of language with the loss of the hafidz. ${ }^{21}$

According to Abdul Ghani Abdullah, the emergence of the idea of Arabic lexicography was influenced by the social and cultural conditions at that time. The life of the Baduwi people who began to penetrate urban areas in the second century Hijriyah meant that the main source and object of the Nahwu and Riwayah experts was nearing extinction so that the scholars felt a great need for the compilation and bookkeeping of every word and even the letters. It is narrated that a scholar named Abu 'Amru ibn Ala liked and pursued the collection of vocabulary arranged in a list that filled his house until it reached the roof of the house. This vocabulary includes odd words or ghari $>b$ and rare or $n a>$ dir which are collected in a treatise or booklet called An Nawa>dir. But as a form of zuhud lifestyle and worshiping he tore up all the vocabulary lists and vacated his house for that, but he could not tear what had been memorized by his students among them were Khalil ibn Ahmad Al Farihidy who took a lot of vocabulary from him and several other scholars such as Abu Malik and Abu Khairah and follow his way in interpretations of vocabulary obtained from Arab Badawy tribes. This is what prompted Khalil bin Ahmad to compose a mu'jam that could contain all the Arabic vocabulary he had. ${ }^{22}$

\section{The Evolution of Arabic Lexicography}

The initial phase of Arabic vocabulary codification begins with the collection of irregular vocabularies, in this phase, the ulama or lexicologist travels to the interior to hear certain vocabulary, then the acquired vocabulary is collected without a certain systematic or pattern, for example, a lexicologist finds vocabulary about ablution matters, commercial matters, inheritance matters, and then he will compile all the randomly obtained vocabulary. ${ }^{23}$

The second phase of codification of Arabic vocabulary begins with the collection of vocabulary based on certain sub-themes. Mu'jam with this system is called ma'a>jimu al $m a^{\prime} a>n i y$ or al ma'a>jim al mubawwabah or thematic dictionary. Qudama scholars in compiling mu'jam ma'aniy classify each vocabulary theme into a special book independent of other themes based on names, types of colors, parts, phases by providing examples in the form of fragments of prose, poetry, proverbs, Hadith, and Al-Qur'an. Therefore, users who want to find the meaning of a word should know the underlying theme of the word. ${ }^{24}$

There are two types of mu'jam ma'any, namely the first mu'jam al ajza' al lughawiyyah which only has one theme, for example, the work of al Ashma'i entitled Khalqu al Insan and Kita $<$ bu al Ibil and Kita $<$ bu al Naba<t wa al Syajar. The second is ma'a<jim al maud $\} u<' a<t s$, especially in the field of linguistics, Abdul Majid divides this type of this mu'jam into 6 kinds

\footnotetext{
${ }^{21}$ Abdul Majid Muhammad Abu Sikkin, al Ma'a >jim al 'Arabiyyah Mada>risuha> wa Mana>hijuha>, p. 18

22 Yasriy Abdul Ghaniy Abdullah, Mu'jamu al Ma'a>jim al 'Arabiyyah, 1st ed., (Beirut: Dar al Jail, 1991), p. 36

${ }^{23}$ Ahmad Amin, Dhuha al Isla>m : Nasy'atu al 'Ulu>m fi> al As fr al 'Abbasy al Awwal, 2nd, (Kairo: Maktabatu al Usroh, 2003, p. 263-264

24 Ahmad ibn Abdullah Al Batuly, al Ma'a>jim al Lughawiyyah wa T\{uruqu Tarti>biha>, 1st ed., (Riyadh: Dar al Rayah, 1992), p.69
} 
based on the style. The first is the odd pattern or Ghari>b and rare or $N a>d i r$ as contained in the work of Abu Zaid al Ansariy entitled an Nawa>dir fi> al Lughah. The second features are sub-themes and treatises or booklets as in the work of Al Ashma'iy entitled al Ajna $>s$ and the work of Abu Zaid al Anshary entitled al Mat\}ar. The third is the pattern of al Ad\}d\}ad or a word that has two meanings as in the work of Al Ashma'iy which is entitled $a l A d\} d\} a d$. The fourth style of Mutsallatsu al Kala $>m$ that contains words that have three different vowel forms with each different meaning as well as in the work entitled Mutsallatsa>ts Qat $\} r a b$. The fifth style of $a l A f^{\prime} a>l$ dzatu alisytiqa $>q$ alWa $\left.>\mathrm{h}\right\}$ id contains the word that has two forms isytiqa $>q$ which are different but have the same meaning as in the work entitled Az Zujaj fa'alats waaf'alats. And last complexion al $H\{u r u>f$ which uses a system of preparation or entries based on the letters, as in the work of Abu Zaid al Anshary entitled Al Hamz. But in this phase, the types of mu'jam ma'any can be divided into three based on their meanings, the first vocabulary that has different meanings or vice versa different meanings contained in one vocabulary as in the work of al Ashma'iy Ma> Ikhtalafats Alfa>z|uhu wa Ittafaqats Ma'a>ni>hi, in al Anbary Ghari>bi al Lughah and al Jawaliqy Ma> Ja>'a 'ala Fa'alats wa Af'alats 'ala H\{uru>fi al Mu'jam. The second the set of vocabulary containing al isytira $>k$ fi $>$ ba'd $\mid i$ al ma'a $>$ niy and classified them into certain groups as in the work of ats Tsa'alabiy entitled Fiqhu al Lughah and the work of al Hamzdzaniy entitled al Alfa>z\} al Kita>biyyah. Third, the set of Arabic vocabularies that are $s y a>z\}$ and $n a>$ dir as well as the object of the dispute between the Nahwu Kufah and Bashrah grammatic scholars as well as about problems in the science of Sharf as in Ibn Khaliwaih's work entitled Laisa Fi> Kala>mi al 'Arabic and the work of Ar Rummany entitled Ma'aniy>al $H\left\{u r u>f .{ }^{25}\right.$

The third phase is the phase of compiling mu'jam with certain systematics and patterns to make it easier for users to find the meaning of the intended vocabulary. In this phase, the preparation of mu'jam is no longer based on meaning or mu'jam ma'aniy, but the arrangement is based on lafadz, word origin, word derivation, and meaning so that it is called mu'jam alfadz or al mu'jam al mujannasah or literal dictionary. . Lexicologists at the time of Khalil bin Ahmad Al Farahidy collected words that were related to one another in a book called Kita>bu al Maudhu'a >ts. The formulation model is not based on a particular system or pattern. So Khalil saw that if he followed in the footsteps of the lexicologists of his time, repetition of words was inevitable and guaranteed completeness of each material will also not be fulfilled. Therefore Khalil innovated in the wording system in Mu'jam with the phonetic system $h\} u r u>f u$ al hija>'i

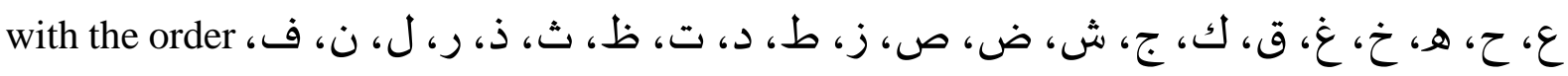
This system stands on the basis of the distribution of votes based on makharij>al $h\} u r f$, starting with al $h\} u r u>f$ al $h\}$ alqiyyah, then al $h\} u r u>f$ al lahwiyyah, then al $h\} u r u>f$ al syajariyyah, then al $h\} u r u>f$ al asalliyah, then al $h\} u r u>f$ al nit $\}$ 'iyyah, then al $h\} u r u>f$ al litsawiyyah, then al $h\} u r u>f a l z\}$ alqiyyah, and last $a l h\} u r u>f a l$ hawa $>$ iyyah. Each letter is named Khalil with $u s>b$, so that the name of his work is we>b al 'ayn because the system of compiling vocabulary or entries begins with the letter 'ayn. ${ }^{26}$

According to Khalil, the Arabic vocabulary cannot be separated from 29 hijaiyyah letters, and he also thinks that every word cannot be separated from a word category consisting

25 Dizirah Saqal, Nasy'atu al Ma'a>jim al 'Arabiyyah wa Tatawwuruha>, 1st ed., (Beirut: Dar al Shadaqoh al 'Arabiyyah, 1995), p. 16

${ }^{26}$ Eimil Ya'qub, al Ma'a >jim al Lughowiyyah al 'Arabiyyah Bada> 'atuha> wa Tatawwuruha> ..., >, p. 41 
of two letters to five letters, so that each vocabulary from each of these categories abniyyah is arranged alternately. where 'ainu al fi'il can be placed in abniyyah tsunaiyyah to be first or second, and in abniyyah tsulatsiyyah to be first, second or third and so on, it will produce a $m u^{\prime} j a m$ that can cover the entire of Arabic vocabulary, this system is called niz $\mid a>m$ at taqli $>b a>t s .{ }^{27}$ Apart from Kalil bin Ahmad al Farahidy, several scholars who have followed the same method, namely the phonetic system, are Ismail ibn Ibad at Thaliqani in his work al Muh \}i $>t\}$ fi> al Lughah, and Abu Mansur Muhammad ibn Ahmad al Azhariy in his Tah\}z\}i>b al Lughah, and Abu Ali Ismail ibn Qasim al Qali al Baghdadiy in his work al Bari>' fi> al Lughah. ${ }^{28}$

The fourth phase is the birth of the codification of Arabic vocabulary into mu'jam form using a systematic and entry pattern called an Niz|a>m al Alfaba>iy al Kha>s\} or a special alphabetical system. Ibn Duraid as a pioneer of special alphabetical system sees the difficulty in the use of the Qur'an with the phonetic system as found in kita>bu al 'ayn Khalil works and other works by the same method. This problem is a lot experienced by people who do not recognize the order of letters based on makhraj. In addition, several dictionaries with the existing phonetic system were considered inconsistent with the order of letters with a phonetic system. Ibn Duraid sees that a dictionary with a system that refers to the arrangement of hijaiyyah letters according to Nasr ibn Ashim is more popular among the public because it is a hijaiyyah letter sequence that has been recognized by the government, scholars, and the public in the preparation of books in various scientific disciplines. But on the other hand, Ibn Duraid also agreed on Khalil's innovation in niz $\mid a>m$ at taqli>ba>ts to cover the entire Arabic vocabulary. Therefore, Ibn Duraid combined these two methods to produce a new compilation or entry system, namely an Niz $\mid a>m$ al Alfaba>iy al Kha>s\} in the compilation of his dictionary called al Jamaharah. ${ }^{29}$

The pattern of arrangement or entry with a special alphabetical system in Ibn Duraid's work is based on al isytiqa $>q$ al akbar. Unlike khalil, Ibn Duraid uses an alphabetical system that starts with the letter hamzah in the form of alif because it is at the beginning of the word, while for the taqli>bats and tashri>fa>ts system he agrees and follows Khalil's method, also in the abniyyah system which is divided into tsunaiy until khumasiy. Although it has differences in the system of compilation and entry of vocabulary. Ibn Duraid al Jamaharah is presumably have a level of equality and a high similarity in terms of content with kita>bu al 'ayn works of Khalil causing speculation that Ibn Duraid was duplicated the work of Khalil which seem that he just replace the cover of his book. In addition to Ibn Duraid, Ibn Faris in compiling his work maqa $>y i>s$ al Lughah also adheres to a special alphabetical system, but this mu'jam cannot be called a general mu'jam of language because it is a special mu'jam which is motivated by his own personal thoughts. So that in this phase of the emergence of a special alphabetical system and the work of Ibn Duraid and Ibn Faris did not bring major and important changes in the history of Arabic lexicography. ${ }^{30}$

The fifth phase is the codification of Arabic vocabulary into mu'jam form with a pattern of arrangement or entry using a rhyming system or an niz $\mid a>m$ al qa $>$ fiyah. The emergence of

${ }^{27}$ Husain Nashar, al Mu'jam al Arabiy Nasy'atuhu wa Tatawwuruhu, 1st, (Kairo: Maktabah Misr, 1956), p. 197

28 Ahmad ibn Abdullah, al Ma'a>jim al Lughawiyyah wa Tathawwuruha>, 1st ed., (Riyadh: Da>r al Rayah, 1992), p.14

${ }^{29}$ Eimil Ya'qub, Al Ma'ajim Al Lughawiyyah Al 'Arabiyyah Bada > 'atuha > wa tatawwuruha>, p. 77

${ }^{30}$ Dizirah Saqal, Nasy'atu al Ma'a >jim al 'Arabiyyah wa Tatawwuruha>..., p. 52 
this system is a new breakthrough in the history of Arabic lexicology and lexicography because it contains major changes in terms of the system. This system is called the rhyming system because the arrangement of the order of words in the mu'jam is based on the order of the last letters of a word as well as the rhymes in poetry. If you want to find the meaning of the word شئ إشـارة you can find it in chapter $r a^{\prime}$ then chapter syin because the origin of the word is just as if you want to find the meaning of the word كاتب then it can be found in chapter $b a^{\prime}$ then chapter kaf because the origin of the word is كتب. The reason why Al Jauhary didn't adopt the same method as its predecessors are due to an obsession with innovation to create new methods that have never been found before, in response to the need for dictionaries that collect words that have rhymes or endings in the same word, a characteristic of Arabic that does not can be separated from the system of isytiqa $>q$ where the final letter or $l a>m$ al fi'il tends to remain and does not change as happened in the first letter or $f a>^{\prime} u$ al fi'il or the second letter or 'ainu al fi'il, and the emergence of many literary works in the form of poetry, prose, songs, proverbs, qasidah which use a lot of poems or words with the same letter endings. ${ }^{31}$

Isma'il ibn Hammad al Jauhary's monumental work that uses a rhyming system is as $S\{i h\} a>h\} T a>j u$ al Lughah wa $S\{a h\} a>h\} u$ al 'Arabiyyah. This mu'jam became one of the major works in the history of the movement of Arabic lexicography development at this phase because it came with an easier chapter arrangement method than its two predecessor mu'jams by Khalil and Ibn Duraid, it also contained a brief and clear explanation of each vocabulary, and pays attention to the problems of Nahwu and Sharf, and points out language weaknesses and downsides. Some of the difficulties experienced by users of mu'jam work by Khalil and Ibn Duraid seem to be answered completely by Al Jauhary, namely the difficulty in classifying al bina' an nau'iy and al bina' al kammiy caused by the arrangement of words or entries based on $h\}$ uru>fu al maddah al as \}liyyah such as tsunaiy, tsulatsiy, ruba'iy and khumasiy and based on word types, namely $s a>$ lim and mu'tal, this type of arrangement or entry model become more difficult to use because all the derivation results of words originating from one maddah are positioned in the same place and entries based on the letters of the alphabet or phonetics. In its preparation, it begins with a classification based on the origin of the word according to the alphabetical system except for the letter waw by paying attention to each letter in the word and the final alignment of the letters of each word, for example in the chapter 'ain then collecting words ending with the letter 'ain, then dhabt for each word with vowels to avoid at tas $\} h\} i>f$. In addition to Al Jauhary's work, there are other works that use the same method, namely the work of Abu Bakar Ar Raziy entitled Mukhta>r al $S\{i h\} a>h$ and Fairuzabardiy's work entitled $A l Q a>m u>s$ al Muh $\} i>t$ \} and Ibn Mandzur's work entitled Lisa>nu al 'Arab. ${ }^{32}$

The sixth phase is the codification of Arabic vocabulary into mu'jam form with a pattern of arrangement or entry using the general alphabetical system or an Niz $\mid a>m$ al Alfaba>iy al ' $A<m$, namely the arrangement pattern based on the origin of the word or root which in Arabic is called awa>ili al $u s\{u>l$. This general alphabetical system uses the hijaiyyah word order which is known until now from alif to $y a^{\prime}$, while the difference with the special alphabetical system lies in the aspect of the root of the word. Arabic lexicography with the system has existed since the time of Imam Bukhari and Ibn Qutaibah, the muhadditsin who first discovered

${ }^{31}$ Eimil Ya'qub, Al Ma'ajim Al Lughawiyyah Al 'Arabiyyah Bada > 'atuha > wa tatawwuruha>..., p. $102-103$

32 Dizirah Saqal, Nasy'atu al Ma'a>jim al 'Arabiyyah wa Tatawwuruha>..., p. 54 
this system than lexicologists to compile the names of hadith narrators by paying attention to the first letter of each narrator's name. Even so, at first this system did not appear perfectly in one phase, but developed from time to time. Some opinions say that the person who first coined this system was Az Zamakhsyari in the sixth century in his work Asa>su al Bala>ghah, but this opinion was refuted by some researchers who said that the originator of this system was Abu al Ma'aliy Muhammad ibn Tamim. Al Barmakiy in his work entitled al Muntaha $>f i>a l$ Lughah which is quoted from as $S\} a h h\{a>h\{$ by al Jauhary. In the end it can be concluded from this dispute that Al Barmaky is the originator of the general alphabetical system, and Zamakhsyari as the first person to perfect the general alphabetical system into the form of mu'jam. ${ }^{33}$

In his work, Zamakhsyari does not follow the same method as his predecessor. In his work, Zamkhsyari collects all vocabularies that begin with the same letter, for example in the word of maddah جدب, which several vocabularies can be found. However in this work Zamakhsyari does not pay much attention to the explanation of each word as much attention to the placement and use of each word in the sentence and the explanation of the use and placement of words in this sentence in a figurative manner as he uses fragments a lot snippets of prose and poetry. Some lexicologists who apply the same method and system as Zamakhsyari are As Syartuniy in his work Aqra>bu al Mawa>rid, Luwis al Ma'luf in his work al Munji>d, Majma' al Lughah al 'Arabiyyah in al Mu'jam al Wasit. ${ }^{34}$

The seventh phase was the codification of Arabic vocabulary into mu'jam form with a pattern of arrangement or entry using an articulation system or an Niz|a>m an Nut\}qiy. An articulation system or an Niz|a>m an Nut $\}$ qiy is a system based on the first letter in a word without looking for the root word first. This is based on the problems faced by learners in the use of mu'jam, especially for beginners and even intermediate levels. Based on this problem, modern lexicologists compile mu'jam using an articulation system to make it easier for users to know the location of the vocabulary even though they do not have Sharf's knowledge. This system has emerged among Arabs for a long time, recorded in al Kafury's work entitled $\mathrm{Al}$ Kulliyya $>t s$ and al Jurjaniy entitled $a l T a^{\prime} r i>f a>t s$, but at that time this system was avoided by the majority of Arabs due to a lack of efficiency. This is caused by confusion in the vocabulary that should be in the same maddah, for example in the word كتاب which can be found in the letter of kaf chapter and meanwhile the word مكتوب which can be found in the letter of mim chapter even though both come from the same maddah. This system then underwent a renewal in the hands of As Shaykh Muhammad Al Bukhariy al Mishry who attempted to combine the entire vocabulary in the two dictionaries Lisa>nu Al 'Arab and $A l Q a>m u>s$ al Muh\}i>t\} with an alphabetical arrangement. And the initial letters of each word without regard to isytiqa $>q$ and tajri $>d$, but this attempt was unsuccessful because he died before the dictionary he was compiling was complete. Then in the decade of the 60s the idea of As Shaykh Muhammad Al Bukhariy al Mishry was developed by Lebanese lexicologists including Shaykh 'Abdullah al Ulayaliy who succeeded in compiling mu'jam with an articulation system without using the system of isytiqa $>q$ entitled al Marja'. And other works such as the work of Jibran Mas'ud

\footnotetext{
${ }^{33}$ Eimil Ya'qub, Al Ma'ajim Al Lughawiyyah Al 'Arabiyyah Bada> 'atuha> wa Tatawwuruha>..., p. $137-138$

${ }^{34}$ Dizirah Saqal, Nasy'atu al Ma'a >jim al 'Arabiyyah wa Tatawwuruha>..., p. 61-68
} 
entitled $\mathrm{Ar} R a>i d$ and the work of Fuad Afram Al Bustany entitled al Munji $>$ d al Abjadiy and Khalil al Jar entitled al Mu'jam al 'Arabiy al Hadi>ts $L a>r u>s$ with articulation system and derivation system or isytiqa $>q .{ }^{35}$

\section{Implications of Arabic Lexicography In Arabic Language Teaching And Learning}

Lexicology and lexicography are two interrelated activities in the field of linguistics, lexicology which is a theoretical scientific study, and lexicography which is a practical study which in the end gives birth to the lexicon or dictionary or mu'jam. Of course, in the process of lexicography and lexicology, it cannot be separated from its sub-study, namely morphology, and semantics. In addition, a lexicon or mu'jam must also meet the syntaxis criteria in it to explain the use of a word in a sentence. ${ }^{36}$

In terms of morphological aspects, a lexicon or mu'jam user is guided to understand morphemes based on allomorphs and the morphs that form them. In addition, users are also required to know the classification of words according to their class and function such as verbs, nouns, adjectives, and others. Errors in understanding the origin of the word or its derivation can cause errors in the search for meaning in mu'jam 'araby. The need for mastery of morphology becomes very important as an introduction before starting to use mu'jam 'araby. Thus the user can use mu'jam 'araby properly and correctly because it makes it a knife for analysis of Arabic vocabulary and terms, besides that, skills in the field of morphology will be further honed by the frequent use of learners using mu'jam 'araby in finding the meaning of the word which is desired.

In terms of the semantic aspect, each word contains several meanings according to the context of the sentence. Just as the word ذهب does not always mean to go, as in the context of fiqh the word ذهب إلى means to believe. Understanding every detail of the meaning of Arabic, especially understanding the meaning of the Qur'an, is not enough just to rely on translation, because the true meaning of Arabic contains explicit and implicit meanings contained in words and series of sentences. This is what makes the awareness to always study the treasures of Arabic vocabulary increasingly important to be encouraged by using the lexicon or mu'jam as its support. Vocabulary and terms in the language Arabic are dynamic and will evolve according to the times, there are terms and vocabulary that can only be found in the classics, and instead, there are many new terms that appear in this modern age that does not exist in the classical books. So that a learner when referring to the use of the lexicon or mu'jam can increase learning knowledge not only about the meaning of the desired word but also the shift in meaning so that the learner can know its placement in a series of good and correct sentences.

In terms of syntax, in order to know the meaning of a word in a sentence, the learner must know the composition of the word in a series of sentences and its function and position as well as in finding the meaning of a word, the learner should also know how to use it in a series of sentences according to the context. The need for good syntactic knowledge in the use of lexicon or mu'jam is becoming more and more real. A learner can put a word in a series of sentences after knowing its meaning according to the context of the sentence, on the other hand, p.164-165

${ }^{35}$ Eimil Ya'qub, Al Ma'ajim Al Lughawiyyah Al 'Arabiyyah Bada > 'atuha > wa Tatawwuruha>...,

${ }^{36}$ Abdul Chaer, Leksikologi dan Leksikografi Indonesia, (Jakarta: Rineka Cipta, 2007), P. 177 
the learner must understand the function and position of the word according to the context of the sentence before looking for its meaning in the lexicon or mu'jam.

\section{CONCLUSION}

The beginning of lexicography though based on the difficulties of understanding the meaning of al Quran which was named by gha>ri>bi al Quran after the advent of Islam in the Arabian peninsula. Arabic lexicography has gone through a long codification phase that gave birth to various dictionaries and various patterns of arrangement or entry systems that are characteristic of the Arabic scientific treasures, especially in the fields of lexicology and lexicography. The lexicon or mu'jam eventually became a forum for the preservation and maintenance of the purity of the Arabic language. Nowadays, the function and role of the lexicon or mu'jam are increasingly marginalized by the existence of an instant transliteration system. Whereas the use of the lexicon or mu'jam in Arabic learning is not only limited to its semantic elements but can also be a forum and a means of developing abilities in learning and applying morphology and syntax.

\section{REFERENCES}

Abdullah, Ahmad ibn. al Ma'a >jim al Lughawiyyah wa Tathawwuruha>. 1st Edition. Riyadh: $\mathrm{Da}>\mathrm{r}$ al Rayah, 1992.

Abdullah, Yasriy Abdul Ghaniy. Mu'jamu al Ma'a>jim al 'Arabiyyah, 1st Edition. Beirut: Dar al Jail, 1991.

Abu Sikkin, Abdul Majid Muhammad. al Ma'a>jim al 'Arabiyyah Mada>risuha> wa Mana > hijuha>, 2nd Edition. Kairo: Al Azhar University, 1981

Al Batuly, Ahmad ibn Abdullah. al Ma'a>jim al Lughawiyyah wa T\{uruqu Tarti>biha>. 1st Edition. Riyadh: Dar al Rayah, 1992.

Al Farj, Muhammad Abu. al Ma'a>jim al Lughawiyyah fi > Dhau'I Dira >sa >t 'Ilm al Lughah al Hadist. Kairo: Da>r an Nahdhoh al 'Arabiyyah, 1966.

Al Hamzawiy, Muhammad Rasyad. Min Qadha>ya> al Mu'jam Qadi>man wa Hadi>tsan, 1st Edition. Tunisia: Dar Gharb al Islamiy, 1986.

Amin, Ahmad. Dhuha al Isla $>m$ : Nasy'atu al 'Ulu>m fi> al As $\} r$ al 'Abbasy al Awwal. Kairo: Maktabatu al Usroh, 2003.

An Nuqrath, Abdullah Muhammad. al Sya>mil fi> al Lughah. Libya: Da>r al Kutub al Wathaniyyah, 2003.

Chaer, Abdul. Leksikologi dan Leksikografi Indonesia. Jakarta: Rineka Cipta, 2007.

Edrisi, Mohammad Hassan and Gholamhossein Sharifi. A Study of Arabic Lexicon their Compilation Methods and development. in Journal of Novel Applied Sciences. Vol. 04, No. 2, 2015.

Hayani, Fitra. Leksikografi Arab (Sebuah Kajian Lingustik Terapan). in Journal Shaut al 'Arabiyyah. Vol. 7, No.1, 2019. 
Kareem, Mahdi Inaayaah al Uthbi \& Sundus Muhsin al Ubaidy. Approaches to Lexicography in English and Arabic. in LARQ Journal for Philosophy and Linguistic and Social Science. Vol. 7, 2012.

Khalil, Hilmy. al Dira>sa>t fi> al Lughah wa al Mu'jam. 1st Edition. Beirut: Da>r al Nahdhoh, 1998.

Murad, Ibrahim ibn. Masa>il fi > al Mu'jam. 1st Edition. Beirut: Da>r al Gharby al Islamiy, 1997.

Nashar, Husain. al Mu'jam al Arabiy Nasy'atuhu wa Tatawwuruhu. Kairo: Maktabah Misr, 1956.

Quthaib, Adnan. al Mu'jam al 'Arabiy baina al Madhy wa al Ha>dir. 2nd Edition. Libanon: Maktabah Lubnan li al Nasyirin, 1994.

Saqal, Dizirah. Nasy'atu al Ma'a>jim al 'Arabiyyah wa Tatawwuruha>. 1st Edition. Beirut: Dar al Shadaqoh al 'Arabiyyah, 1995.

Setiadi, Alif Cahya. Tarikhu Nasy'ati al Ma'ajim al 'Arabiyyah. in Journal Lisanu Dhad. Vol. 02, No. 2, 2015.

Umar, Ahmad Mukhtar. S\{ina> 'atu al Mu'jam al H\{adi>ts. Kairo: 'A>lamu al Kutub, 2009.

Ya'qub, Eimil. Al Ma'a > jim al Lughowiyyah al 'Arabiyyah Bada> 'atuha> wa Tatawwuruha>, 1st Edition. Beirut: Dar al 'Ilm li Al Malayin, 1981.

Zaidan, George. Tari>kh Adab al Lughah al 'Arabiyyah. Beirut: Da>r al Fikr. 